\title{
TRANSFORMATION OF KHATAMAN AL-QUR'AN IN THE PANDEMIC TIME OF COVID-19
}

\author{
May Salwa Billah Safirah, Agus Machfud Fauzi \\ Universitas Negeri Surabaya, Indonesia \\ May.18016@mhs.unesa.ac.id, agusmfauzi@unesa.ac.id
}

\begin{abstract}
Khataman Al-Quran is the activity of reading Al-Quran which starts from surah alFatihah to surah an-Naas. Khataman Al-Quran is one of the religious activities carried out by Fatayat Muslimat NU (Nahdatul Ulama) Sarirejo. Khataman Al-Quran can transform when its implementation is disturbed. As was the case when there was a covid-19 pandemic outbreak, all forms of religious activities of the NU Muslim Fatayat underwent a transformation. The purpose of this study was to analyze the transformation of the Khataman Al-Quran carried out by Fatayat Muslimat NU during the Covid-19 pandemic. Researchers used qualitative methods because, in accordance with the research discussion, the results could not be measured by NUmbers but by using words. The data collection techniques used were observation and in-depth interviews. The theory used in this research is Talcott Parson's AGIL theory. There are 4 things that are interconnected, namely adaptation, goal attainment, integration, and latency. The result of this research is that the Khataman al-Qur'an carried out by Fatayat Muslimat NU in Sarirejo District underwent a transformation during the Covid-19 pandemic. The transformation that occurred was the change in reading the khataman Al-Quran face-to-face in Sarirejo Subdistrict to face-to-face reading in each village and being guided online by the Fatayat Muslimat NU, Sarirejo District. The transformation occurred because there were restrictions on community activities in order to stop the spread of covid-19.
\end{abstract}

Keywords: Covid-19, Fatayat Muslimat NU, Khataman Al-Qur'an

\section{Abstrak}

Khataman al-qur'an adalah kegiatan membaca al-qur'an yang dimulai dari surah al-fatibah sampai dengan surah an-naas. Khataman Al-Quran menjadi salah satu kegiatan keagamaan yang dilaksanakan fatayat muslimat NU Sarirejo. Khataman Al-Quran bisa bertransformasi ketika dalam pelaksanaannya mengalami gangguan. Seperti halnya ketika terdapat wabah pandemi covid19, segala bentuk kegiatan keagamaan fatayat muslimat NU mengalami transformasi. Tujuan dari penelitian ini adalah untuk menganalisis transformasi khataman Al-qur'an yang dilakukan oleh Fatayat muslimat NU pada masa pandemi covid-19. Peneliti menggunakan metode kualitatif karena sesuai dengan pembahasan penelitian yang hasilnya tidak bisa diukur dengan angka melainkan menggunakan kata-kata. Teknik pengumpulan data yang digunakan adalab obsevasi dan wawancara mendalam. Teori yang digunakan dalam penelitian ini yaitu teori AGIL dari Talcot Parson. Terdapat 4 hal yang saling berbubungan yaitu adaptasi, goal attainment, integrasi dan latency. Hasil dari penelitian ini yaitu khataman al-qur'an yang dilakukan oleh fatayat muslimat NU di Kecamatan Sarirejo mengalami transformasi selama masa pandemi covid-19. 
Transformasi yang terjadi yaitu beralihnya pembacaan khataman al-qur'an secara tatap muka di Kecamatan Sarirejo menjadi pembacaan tatap muka di desa masing-masing dan dipandu secara online oleh pengurus fatayat muslimat NU Kecamatan Sarirejo. Transformasi terjadi karena terdapat pembatasan kegiatan masyarakat demi untuk menghentikan penyebaran covid-19.

Kata kunci: Covid-19, Fatayat Muslimat NU, Khataman Al-Qur'an

\section{INTRODUCTION}

Corona virus is an RNA virus with a particle size of 120-160 nm. Corona virus is a virus that attacks the respiratory system, a disease caused by this virus is known as covid-19. The impact on people who are infected with the corona virus can have a mild, severe impact to lose their life or die ${ }^{1}$. The spread of covid-19 in Indonesia began in March with details of 2 people exposed to covid-192. As time went on, the spread of covid-19 also experienced a very drastic increase, so that the government through the Ministry of Health issued a new regulation on large-scale social restrictions (PSBB). Regulations are not only issued by the Ministry of Health, but regulations are also issued by the Ministry of Religion.

The Ministry of Religion regulation is outlined in the circular letter of the Minister of Religion No. 23 of 2020 concerning guidelines for organizing worship activities and Christmas celebrations during the Covid-19 pandemic. Through a circular from the Minister of Religion, there are restrictions on religious activities in order to reduce covid-193. Restrictions on religious activities have led to new debates within the community. Through this debate, two groups of people emerged, namely some people accepted it and some people rejected it. Restrictions on religious activities are not only applied in a large area, but also in a small area. As with the restrictions on religious activities of Fatayat Muslimah NU in Sarirejo District, Lamongan Regency.

Fatayat Muslimat NU is an autonomous body of NU dedicated to female members of NU. Actually fatayat and Muslimat NU have differences in terms of activities and ages of women who participate in them ${ }^{4}$. But in Fatayat Muslimat NU sarirejo there is no difference. The two of them joined together to strengthen and run the NU women's organization at the sub-district level. Fatayat Muslimat NU has five work program areas, namely law, politics, advocacy, preaching, and member development. Fatayat Muslimat NU has an important role in the fields of religion, education, social, economy and politics ${ }^{5}$. Through these areas, the focal point of this article is Fatayat Muslimat NU's religious activities during the Covid-19 pandemic.

1 Aditya Susilo et al., “Corona Virus Disease 2019: Review Of Current Literaturs”, Jurnal Penyakit Dalam Indonesia7, no. 1 (2020): 45-67

${ }^{2}$ Yuliana, "Corona Virus Diseases (Covid-19): Kajian Literatur", Journal Wellness And HealthyMagazine 2, no. 1 (2020): 87

${ }^{3}$ Kemenag, Panduan PenyelenggaraanKegiatan Ibadah dan Perayaan Natal DimasaPandemi Covid-19, Jakarta: Kementrian Agama Republik Indonesia, 2020).

4 Sri Roviana, "Gerakan Perempuan Nadhlatul Ulama Dalam Transformasi Pendidikan Politik", Jurnal Pendidikan Islam 3, no. 2 (2014): 403

5 Tyas Asih Ismiati, "The Role Of Muslimat Organization Nadhlatul Ulama AS A Women: 1950-1999 Kediri Regency”, Simki-Pedagogia 1, no. 9 (2017): 1-10 
Fatayat Muslimat NU Sarirejo has religious activities including routine recitation, khataman al-quran, commemoration of Islamic holidays, rotibul hadda and reading of yasin ${ }^{6}$. Before the Covid-19 pandemic, all activities were carried out directly or face-to-face by all members of Fatayat Muslimat NU Sarirejo. Religious activities were held in the NU building, Sarirejo District. Along with the spread of covid-19 and the existence of a circular from the Ministry of Religion, all forms of Fatayat Muslimat NU's activities have undergone a transformation. Many activities of Fatayat Muslimat NU that must be stopped, namely routine recitation, Islamic holiday (PHBI), rotibul haddat and yasin recitation.

Whereas the Khataman Al-Quran activities were still carried out during the Covid-19 pandemic, but there was a transformation in their activities. Before the Covid-19 pandemic, Khataman Al-Quran activities were carried out for 3 months face-to-face. Khataman AlQuran carried out by gathering together in the NU building kecamtan sarirejo. But during the Covid-19 pandemic there was a transformation in the activities of khataman al-quran. The transformation that occurred was that the khataman Al-Quran switched to readings at the village level and contained directly online by the Fatayat Muslimat NU administrators at the Sarirejo District level. The transformation that occurred gave rise to rejection and acceptance of Fatayat Muslimat NU Sarirejo.

Research on religious activities during the Covid-19 pandemic has been researched by several people. The first research was during the Covid-19 pandemic, Nahdlatul Ulama used the internet as a medium for information and the implementation of religious activities ${ }^{7}$. The second research is that religious beliefs can have a good effect on society to avoid the Covid19 pandemic $^{8}$. The third research, namely the limitation of religious activities during the Covid-19 pandemic, has a strong foundation when viewed from human rights legal instruments ${ }^{9}$. The fourth research, namely during the Covid-19 pandemic, the community's religious activities experienced changes. The changes that occur can be seen through the level of worship, the level of participation, the suggestion of social distancing, and the rationality of Muslims ${ }^{10}$. The fifth research is that most people accept the circular letter of the Minister of Religion on procedures for worshiping during the pandemic well ${ }^{11}$.

Based on five previous studies that explain changes in religious activities during the Covid-19 pandemic, it shows that the community accepted changes in religious activities during the Covid-19 pandemic. The public believes that changes must be made in order to stop the spread of covid-19 and as a form of compliance with the circular issued by the

${ }^{6}$ Hikmah NUr Hidayat and Agus Trilaksana,"Perkembangan Muslimat NU Cabang Lamongan Bidang Ekonomi dan Koperasi Kelompok Usaha Bersama (Kube) Tahun 1994-2015”, AVATARA, e-Juurnal Pendidikan Sejarah 5, no. 3 (2017): 584

7 Muhammad Irfan Wahid, "Dari Tradisional MeNUju Digital: Adopsi Internet Oleh Nadlatul Ulama Selama Pandemi Covid-19", Jurnal Studi Agama dan Masyarakat 16, no. 1 (2020): 73-84

8 Alma'a Cinthya Hadi, "Dinamika Keberagaman Masyarakat Pada Masa Pandemik Covid-19 MeNUju Kenormalan Baru Di Desa Polso Ngawi”, Religi: Jurnal Studi Agama-Agama 16, no. 2 (2020): 188-207

9 Faiq Tobroni, "Pembatasan Kegiatan Keagamaan Dalam Penanganan Covid-19", Jurnal Komunikasi Hukum (JKH) 2, no. 2 (2020): 207

${ }^{10}$ Dadang Darmawan et al., "Sikap Keberagaman Masyarakat Menghadapi Wabah Covid-19", Religius: Jurnal Studi Agama-Agama dan Lintas Budaya 4, no. 2 (2020): 115

11 Meliza, Deri Wanto, and Lukman Asha, "Persepsi Masyarakat Sukaraja, Rejang Lebong Terhadap Edaran Menteri Agama Nomor: SE. 6 . Tahun 2020 Mengenai Tata Cara Beribadah Saat Pandemi”, Jurnal Penelitian Dan Pengabdian Masyarakat (MANHAJ) 9, no. 1 (2020): 1-17 
Ministry of Religion. Based on these five previous studies, there are differences with the transformation of the khataman Al-Quran Fatayat Muslimat NU in Sarirejo. In the transformation of the Khataman Al-Quran Fatayat Muslimat NU activities, there are two differences of opinion, namely those who accept transformation and those who do not.

In communities who accept the transformation, it occurs at the NU management at the District level. This acceptance is based on the idea that transformation is carried out to stop the spread of Covid-19 and as a form of compliance with regulations issued by the Ministry of Religion. Meanwhile, the community who did not accept it happened to members of the Fatayat Muslimat NU at the village level. The rejection that occurs is based on the idea that transformation will only cause trouble, cannot keep in touch with members of the Fatayat Muslimat NU from other villages, and khataman must be done in order to get Allah's intercession and as a place to pray while asking to stop the spread of Covid-19. Rejection was shown by contiNUing to perform khataman Al-Quran directly at the village level guided online by Fatayat Muslimat NU Sarirejo administrators.

\section{METHODS}

The author uses a qualitative approach, because it is in accordance with the research discussion where the results cannot be measured by NUmbers but using words ${ }^{12}$. Researchers use a descriptive type ${ }^{13}$, to explain the transformation of the cataman Al-Quran during the Covid-19 pandemic. To see the transformation of Khataman Al-Quran during the Covid-19 pandemic, the author uses an ethnometodological perspective. According to Garfinkel, ethnometodology is the existence of a person to understand people's common sense knowledge. Garfinkel's ethnometodological perspective is inseparable from figures, such as Talcott Parsons, Edmund Husserl, and Alfred Schudz ${ }^{14}$. Ethnometodology is used to understand phenomena that occur in the community, through observations made by other people $^{15}$.

The research was conducted in Sarirejo District, Lamongan Regency. The research subjects were 4 members of Fatayat Muslimat NU Sarirejo, 2 members of Fatayat Muslimat NU in Beru village, 2 members of Fatayat Muslimat NU in Canggah village, and 2 members of Fatayat Muslimat NU in Simbatan village. Administrators are involved in research activities, because administrators implemented the Khataman Al-Quran transformation during the Covid-19 pandemic. Meanwhile, members consisting of several villages were involved, because those who would receive the Khataman Al-Quran transformation during the Covid19 pandemic.

The data collection techniques used by the author were observation and in-depth interviews. Meanwhile, the data analysis techniques used were data reduction, data presentation and conclusion drawing. The theory used in this research is AGIL from Talcot Parsons. In the AGIL theory, there are 4 interconnected things, namely adaptation, goal

${ }^{12}$ FX Sri Sadewo, Meneliti Itu Mudah (Petunjuk Praktis Untuk Melakukan Penelitian Sosial Kualitatif), ed. MartiNUs Legowo, Unesa University Press, 1 st ed. (Surabaya: Unesa University Press, 2016)

${ }^{13}$ W. Lawrence Neuman, Social Research Methods: Qualitative Approaches, Pearsons New Interatioal Edition, 7th ed (London,1991)

${ }^{14}$ Harold Garfinkel, “Etnomethodology’s Program”, Social Psychology Quarterly 59, no. 1 (1996): 5-21

15 Sadewo, Meneliti Itu Mudah (Petunjuk Praktis Untuk Melakukan Penelitian Sosial Kualitatif) 
attainment, integration and latency ${ }^{16}$. The formulation of the problem in this study is how the transformation of the khataman Al-Quran fatayat Muslimat NU during the Covid-19 pandemic.

\section{RESULTS AND DISCUSSION}

\section{Results}

Covid-19 is a virus that attacks the human respiratory system. The spread of covid-19 in Indonesia is so fast that many people are infected with Covid-19. The spread does not only occur in urban communities, but also reaches rural areas. Covid-19 paralyzes all fields in society, including politics, economics, health and religious activities. The greatest paralysis is deeply felt by the rural community. In fact, rural communities still hold fast to religion, but during the Covid-19 pandemic it caused a decline in community religion. Many religious activities must be stopped in order to stop the spread of covid-19. Like the khataman AlQuran activities organized by Fatayat Muslimat NU Sarirejo.

Khataman Al-Quran activities must undergo a transformation due to the impact of the Covid-19 pandemic. The transformation that occurred was the change in reading the khataman Al-Quran face-to-face in Sarirejo Subdistrict to face-to-face reading in each village and being guided online by the Fatayat Muslimat NU management in Sarirejo District. The Kahataman Al-Quran transformation was not necessarily well received by the community, but there were community groups who rejected it. This happens because there are different perceptions between one society and another.

Based on the results of interviews with Fatayat Musimat officials, NU Sarirejo, it was shown that the management accepted the transformation well. This happened because the management wanted to comply with regulations issued by the state and the ministry of religion, and to help stop the spread of covid-19. The transformation of khataman Al-Quran was also carried out because the management did not want to take the biggest risk with the spread of covid-19. Fatayat considers that during the Covid-19 pandemic all religious activities must adapt to the new environment. Adaptation to religious activities must really be done in order to stop the spread of covid-19.

Fatayat Muslimat NU Sarirejo has religious activities including routine recitation, khataman al-quran, commemoration of Islamic holidays (PHBI), rotibul hadda and yasin recitation. Before the Covid-19 pandemic, all activities were carried out directly or face-to-face by all members of Fatayat Muslimat NU Sarirejo. Religious activities were held in the NU building, Sarirejo District. Along with the spread of covid-19 and the existence of a circular from the Ministry of Religion, all forms of Fatayat Muslimat NU's activities have undergone a transformation. Many activities of Fatayat Muslimat NU that must be stopped, namely routine recitation, Islamic holiday (PHBI), rotibul haddat and yasin recitation.

Whereas the Khataman Al-Quran activities were still carried out during the Covid-19 pandemic, but there was a transformation in their activities. Before the Covid-19 pandemic, Khataman Al-Quran activities were carried out for 3 months face-to-face. Khataman AlQuran carried out by gathering together in the NU building kecamtan sarirejo. But during the

16 Mohammad Syawaludin, “Alasan Talcoott Parsons Tentang Pentingnya Pendidikan Kultur”, Jurnal Ijtimaiyya 7, no. 1 (2014): 2-18 
Covid-19 pandemic there was a transformation in the activities of khataman al-quran. The transformation that occurred was that the khataman Al-Quran switched to readings at the village level and contained directly online by the Fatayat Muslimat NU administrators at the Sarirejo District level.

The main goal of transforming khataman Al-Quran is to help the state to stop the spread of covid-19 and so that more people are not exposed to covid-19 in Sarirejo District. This transformation also occurred because in Sarirejo District, there were people who were exposed to Covid-19. In order to stop this, the fatayat Muslimat officer NU Sarirejo must accept the existence of a regulation from the Ministry of Religion. The previous transformation of the khataman Al-Quran had to be approved by the management and members of the NU Muslimat fatayat in several villages. So that when the two parties are united, there will be no rejection made by members of the Fatayat Muslimat NU.

Based on the results of interviews with members of the Fatayat Muslimat NU Beru, it shows that members reject this transformation. The rejection of the transformation of the Khataman al-qur'an is based on the idea that transformation will only raise new problems, cannot be in direct contact with other members of the fatayat muslimat, kahataman al-qur'an must be done in order to get intercession of Allah, and as a place to pray while asking to stop the spread of covid-19. The rejection was made because of the strong belief and belief in religion, so that through that belief Allah will avoid the Covid-19 virus.

The rejection made by members of the Fatayat Muslimat NU Desa Beru was to contiNUe to do khataman Al-Quran directly or face to face. Members of the Fatayat Muslimat NU dared to refuse because the activities carried out did not bring in people from outside and were only carried out by members in Beru Village. This strong assumption cannot be eliminated because it is deeply rooted in the people of Beru Village. Moreover, the members of the NU Beru Muslimat fatayat are on average over age, so they will experience difficulties having to carry out the transformation of kahataman Al-Quran by using online media. Although currently technological advances are very fast, most of the members of the NU Beru fatayat Muslimat are not technologically illiterate (clueless).

This is different from the members of the Fatayat Muslimat NU in Simbatan Village. Based on the results of the interview, it shows that the members of the Fatayat Muslimat NU Simbatan accepted this transformation well. The background for this acceptance is the large NUmber of members of the Fatayat Muslimat NU. Through this, acceptance is done well. members of the fatayat mulimat NU Simbatan are still thinking about the impact that will arise when the transformation is not carried out. In Simbatan Village, there are 2 overseas people who when they return home are tested positive for Covid-19. Through this, it is true that all community activities are stopped. This stopping was carried out to get rid of the covid-19 virus in the village of Simbatan.

Through the covid-19 pandemic that attacked 2 people in the Simbatan community, adaptation must really be done. The adaptations carried out are between community activities and the presence of Covid-19. The adaptation carried out by the community is in the form of stopping all activities in Simbatan Village. The spread of covid-19 in Simbatan Village immediately gave strong thoughts to the importance of health. Many people improve their health and stop all activities, especially religious activities. In Simbatan Village, there were very 
many religious activities and during the Covid-19 epidemic, all of these activities had to be stopped.

The thoughts of members of the Fatayat Musimat NU in Simbatan village are closely integrated with the covid-19 pandemic, so that they can accept the transformation well. Through this, the goal of transforming khataman Al-Quran can be realized. Even though the Khataman Al-Quran transformation is carried out, Members can more specifically draw themselves closer to Allah. Engagement will be obtained because you do more religious activities at home, so that there are no other disturbances. Most of the informants assumed that by doing khataman Al-Quran directly, they did not get absorbed because members who had not read yet would chat with other members.

Whereas the members of the Fatayat Muslimat NU in Canggah village from the start rejected the transformation of the Khataman Al-Quran activities. Most of the members in Canggah village are old, so they prefer to do Khataman Al-Quran in person or face to face. Canggah village members consider that the person infected with Covid-19 is indeed destiny that must be accepted and dealt with sincerely. Through this, members in Canggah village objected. There are relatively few members of the Fatayat Muslimat NU, so the activities of Khataman Al-Quran are carried out face-to-face without being guided online by the officials of the Fatayat Muslimat NU Sarirejo.

Even though the adaptation of activities must be carried out in order to stop the spread of covid-19, the relationship with Allah and the community must be maintained properly. So that through this integration can be put together properly. Integration with Allah must be done well. Because when we can unite well, all the prayers to stop the spread of covid-19 can be granted by Allah. Whereas integration between Members must also be done in order to get intercession from Allah. Through this, integration must be enhanced between Allah and the Member. These two things cannot be separated just like that, because they are related to each other for the good of life.

\section{Discussion}

\section{Fatayat muslimat NU}

Fatayat Muslimat NU is an autonomous body of NU dedicated to female members of NU. Actually fatayat and Muslimat NU have differences in terms of activities and ages of women who participate in them. Fatayat NU is one of the women's organizations part of the largest Islamic organization in Indonesia, namely Nahdlatul Ulama (NU), and makes NU the parent organization. Thus Fatayat NU has the same organizational principles as $\mathrm{NU}$, which is to adhere to the doctrine of tolerance, to be accommodative and to strive to fight for the tradition of practice and understanding of Islamic teachings in accordance with Indonesian culture. In other words, NU defines itself as the guardian of traditions by maintaining the Ahlu Sunah wal Jama'ah understanding.

Fatayat NU is a women's organization under Nahdatul Ulama. This organization was formed as a form of NU's response to women in order to gain additional insight and deepening of religion. Fatayat was formed as an organization of young NU women who are religious, familial, social and national in nature, and aim at the formation of young Muslim women or women who fear Allah SWT, have good character, and are useful for religion, the country and the nation. 
So what is meant by the role of Fatayat NU is a series of behaviors that are expected by women to get equal rights to religious education. Through this, then, the NU fatayat was established. Fatayat NU is an organization that is able to accommodate and provide direction to young women who have creative and creative souls. Through this, it can illustrate that women also have a very important role.

Most of NU's fatayats have the same vision and mission. The vision is the formation of young Muslims or young women who fear Allah SWT, are virtuous, do good, are capable and responsible and are useful for the Religion of NUsa and the Nation. Meanwhile, the mission is to create a sense of loyalty to the principles, Aqidah and objectives of the Nahdlatul Ulama (NU) in upholding Islamic law. Through this vision and mission, the objectives of Fatayat NU are; the formation of young Muslim women who fear Allah, are moral, have good morals, are capable and responsible, useful for Religion, NUsa and the Nation; the realization of a gender-just society according to its portion; manifesting a sense of loyalty to the principles, aqidah and goals of NU in upholding Islamic law.

Meanwhile, Muslimat NU is one of the largest organizations in Indonesia which can be a forum for self-development for mothers. In this religious organization, mothers (Muslim) have the opportunity to learn many things such as how to organize, appear in public, administration, economic development through cooperatives, especially religious knowledge through the field of da'wah.

The establishment of Muslimat NU was actually inseparable from the enthusiasm of the NU people who at that time fought against the invaders. Even though at that time the Muslimat NU organization had not been formally formed, the fighting spirit of women had shown its participation in fighting the invaders. Muslimat NU has a goal; realization of women who are aware of religion, nation and state. The realization of qualified, independent and devoted Indonesian women to Allah SWT; and the realization of Indonesian women who are aware of their obligations and rights according to the teachings of Islam, both as individuals and as members of society.

Meanwhile, the Fatayat Muslimat NU Sarirejo has no differences. The two of them joined together to strengthen and run the NU women's organization at the sub-district level. Fatayat Muslimat NU has five work program areas, namely law, politics, advocacy, preaching, and member development. Fatayat Muslimat NU has an important role in the fields of religion, education, social, economy and politics. Through these areas, the focal point of this article is Fatayat Muslimat NU's religious activities during the Covid-19 pandemic.

Fatayat Muslimat NU Sarirejo has religious activities including routine recitation, khataman al-quran, commemoration of Islamic holidays (PHBI), rotibul hadda and yasin recitation. Before the Covid-19 pandemic, all activities were carried out directly or face-toface by all members of Fatayat Muslimat NU Sarirejo. Religious activities were held in the NU building, Sarirejo District. Along with the spread of covid-19 and the existence of a circular from the Ministry of Religion, all forms of Fatayat Muslimat NU's activities have undergone a transformation. Many activities of Fatayat Muslimat NU that must be stopped, namely routine recitation, Islamic holiday (PHBI), rotibul haddat and yasin 
recitation. The flagship activity of the Fatayat Muslimat NU is the khataman Al-Quran which is contiNUously carried out, with a period of 3 months.

\section{The transformation of khataman al-qu'ran during the covid-19 pandemic}

Corona virus is a virus that attacks the respiratory system, a disease caused by this virus is known as covid-19. The spread of covid-19 in Indonesia began in March with details of 2 people exposed to covid-19. As time went on, the spread of covid-19 also experienced a very drastic increase, so that the government through the Ministry of Health issued a new regulation on large-scale social restrictions (PSBB). Regulations are not only issued by the Ministry of Health, but regulations are also issued by the Ministry of Religion.

The Ministry of Religion Regulation is outlined in the circular letter of the Minister of Religion No. 23 of 2020 concerning guidelines for organizing worship activities and Christmas celebrations during the Covid-19 pandemic. Through a circular from the Minister of Religion, there are restrictions on religious activities in order to reduce Covid19. Restrictions on religious activities have led to new debates within the community. Through this debate, two groups of people have emerged, namely some people accept it and some people reject it. Restrictions on religious activities are not only applied in a large area, but also in a small area. As with the restrictions on religious activities of Fatayat Muslimah NU in Sarirejo District, Lamongan Regency.

The very fast and increasing spread of covid-19 necessitates a transformation in religious activities. As well as the activities of khataman al-quran. The transformation was carried out in order to stop the spread of covid-19 which contiNUes to increase and comply with the state government and the ministry of religion. The activities of Khataman Al-Quran were still carried out during the Covid-19 pandemic, but there was a transformation in their activities. Before the Covid-19 pandemic, Khataman Al-Quran activities were carried out face-to-face every 3 months. Khataman Al-Quran carried out by gathering together in the NU building kecamtan sarirejo. But during the Covid-19 pandemic there was a transformation in the activities of khataman al-quran. The transformation that occurred was that the khataman Al-Quran switched to readings that were carried out at the village level as well as being sent directly online by the Fatayat Muslimat NU administrators at the Sarirejo sub-district level. The transformation that occurred gave rise to rejection and acceptance of Fatayat Muslimat NU Sarirejo.

The impact of the transformation of khataman al-qu'ran during the Covid-19 pandemic

The spread of covid-19 has had a huge impact on people's lives. As in the fields of economy, politics, health, education and religious activities. In religious activities, the impacts that arise are the cessation of religious activities and the transformation of religious activities. The impacts that arise are not only positive but also negative. The positive impact can be seen in the management and members of the Fatayat Muslimat NU who accept it. Meanwhile, the negative impact can be seen from the members of the Fatayat Muslimat NU who refuse.

The management of the Fatayat Muslimat NU Sarirejo and members of the Fatayat Muslimat NU Simbatan accepted this transformation of the Khataman Al-Quran well. This happened because the management and members of Simbatan Village wanted to comply 
with regulations issued by the state and the ministry of religion, and to help stop the spread of covid-19. The transformation of khataman Al-Quran was also carried out because the management and members in Beru Village did not want to take the biggest risk with the spread of covid-19. Fatayat considers that during the Covid-19 pandemic all religious activities must adapt to the new environment. Adaptation to religious activities must really be done in order to stop the spread of covid-19.

The main goal of transforming khataman Al-Quran is to help the state to stop the spread of covid-19 and so that more people are not exposed to covid-19 in Sarirejo District. This transformation also occurred because in Sarirejo District, there were people who were exposed to Covid-19. In order to stop this, the fatayat Muslimat officer NU Sarirejo must accept the existence of a regulation from the Ministry of Religion. The previous transformation of the khataman Al-Quran had to be approved by the management and members of the NU Muslimat fatayat in several villages. So that when the two parties are united, there will be no rejection made by members of the Fatayat Muslimat NU.

Meanwhile, the negative impact can be seen from the rejection made by members of Beru Village and Canggah Village. The rejection of the transformation of the Khataman alqur'an is based on the idea that transformation will only raise new problems, cannot be in direct contact with other members of the fatayat muslimat, kahataman al-qur'an must be done in order to get intercession of Allah, and as a place to pray while asking to stop the spread of covid-19. The rejection was made because of the strong belief and belief in religion, so that through that belief Allah will avoid the Covid-19 virus.

The refusal made by members of the Fatayat Muslimat NU, Beru and Canggah Villages was to contiNUe to do khataman Al-Quran directly or face to face. Members of the Fatayat Muslimat NU dared to refuse because the activities carried out did not bring in people from outside and were only carried out by members in the villages of Beru and Canggah. This strong assumption cannot be dismissed because it is deeply rooted in society. Moreover, the members of the Fatayat Muslimat NU Beru and Canggah are on average over age, so that they will experience difficulties having to transform kahataman Al-Quran by using online media. Although currently technological advances are very fast, most of the members of the Fatayat Muslimat NU Beru and Canggah are not technologically illiterate (clueless).

\section{Analysis of phenomena with the theory used}

This article uses Talcot Parsons' AGIL theory. The AGIL theory describes religious activity as a system. So that religious activity is a system that has a function. The religious activity system will experience changes when there is a disturbance in the activity process. Changes in the system of religious activities were carried out so that activities could contiNUe to run. There are 4 things discussed in AGIL theory, namely adaptation, goal attainment, integration and latency.

The adaptation that occurs, namely the transformation of religious activities occurs due to adjustments to environmental conditions. as well as the transformation of this khataman al-quran. The activities of khataman Al-Quran fatayat Muslimat NU must be able to adapt to environmental conditions. During the Covid-19 pandemic, many activities of 
residents have experienced disruption, so there are many activities that must be stopped. Through this, new adaptations must be made so that activities can run again. During the Covid-19 pandemic, transformation occurred because it was a form of adaptation shown so that religious activities or khataman Al-Quran could contiNUe.

In the goal attainment, in the transformation of khataman Al-Quran there are goals that must be achieved, namely the activities of khataman Al-Quran to contiNUe and stop the spread of covid-19. The main objective of the transformation of khataman Al-Quran is to help the state to stop the spread of covid-19 and so that more people are not exposed to covid-19 in Sarirejo District. This transformation also occurred because in Sarirejo District, there were people who were exposed to Covid-19. In order to stop this, the fatayat Muslimat officer NU Sarirejo must accept the existence of a regulation from the Ministry of Religion. Another goal to be achieved is that the activities of the Khataman Al-Quran can still be carried out. This is difficult to eliminate because it has become a routine activity that is always carried out by Fatayat Muslimat NU.

In integration, namely the transformation of the khataman al-quran, one must unite between the officials of the Fatayat Muslimat NU Sarirejo and the members of the Fatayat Muslimat NU in the village. Integration must be observed properly so that the two worlds can support each other so that the transformation of Khataman Al-Quran activities can contiNUe in the midst of the Covid-19 pandemic outbreak. When integration is increased between the two, resistance can be slowly removed. Meanwhile, latency is a system that is undergoing changes that must complement, maintain and improve. This must be done so that the transformation of the Khataman Al-Quran can be carried out properly.

\section{CONCLUSION}

During the Covid-19 pandemic there was a transformation of khataman Al-Quran Fatayat Maulsimat NU Sarirejo. The transformation that occurred was the change of face-toface khataman Al-Quran in the district to online and face-to-face khataman in the village. the transformation of khataman Al-Quran is not only well received, but there is also resistance. The Fatayat Muslimat NU board and members in the village of Simbatan received it well. This happened because to help stop the spread of covid-19 and comply with the notification from the ministry of religion. Meanwhile, members of the Fatayat Muslimat NU, Beru and Canggah Villages did their rejection. Refusals were made because they were less effective and would only make it difficult for members to use online. The transformation of khataman Al-Quran can have both positive and negative impacts. The positive impact is that it can help stop the spread of covid-19. Meanwhile, the negative impact was felt by members of the Fatayat Muslimat NU, Beru and Canggah Villages.

\section{Suggestion}

This limitation of religious activities is indeed very good to do because it is in order to stop the spread of covid-19. But the government or the ministry of religion must also look at the condition of society before determining this. When this is done, there will be no resistance from the community. Meanwhile, members of the Fatayat Muslimat should comply with regulations issued by the Ministry of Religion. because this has a good purpose in order to stop the spread of covid-19. 


\section{REFERENCES}

Darmawan, Dadang, Deni Miharja, Roro Sri Rejeki Waluyojati, Erni Isnaeniah. "Sikap Keberagaman Masyarakat Menghadapi Wabah Covid-19." Religious: Jurnal Studi AgamaAgama dan Lintas Budaya 4, no. 2 (2020): 115.

Garfinkel, Harold. "Etnomethodology's Program." Social Psychology Quarterly 59, no. 1 (1996): 521.

Hadi, Alma'a Cinthya. "Dinamika Beragama Masyarakat Pada Masa Pandemi Covid-19 MeNUju Kenormalan Baru Di Desa Ploso Ngawi." Religi: Jurnal Studi Agama-Agama 16, no. 2 (2020): 188-207.

Ismiati, Tyas Asih. "The Role Of Muslimat Organization Nadhatul Ulama AS A Women: 1950-1999 Kediri Regency." Simki-Pedagogia 1, no. 9 (2017): 1-10.

Kemenag. Panduan Penyelengaraan Kegiatan Ibadah Dan Perayaan Natal Dimasa Pandemi Covid-19. Jakarta: Kementrian Agama Republik Indonesia, 2020.

Meliza, Deri Wanto, Lukman Asha. "Persepsi Masyarakat Sukaraja, Rejang Lebong Terhadap Edaran Menteri Agama Nomor: SE. 6. Tahun 2020 Mengenai Tata Cara Beribadah Saat Pandemi." Jurnal Penelitian dan Pengabdian Masyarakat (MANHAJ) 9, no. 1 (2020): $1-17$.

Neuman, W Lawrence. Social Research Methods: Qualitative and Quantitative Approaches. 7. London: Pearsons New International, 1991.

Roviana, Sri. "Gerakan Perempuan Nadhatul Ulama Dalam Transformasi Pendidikan Politik." Jurnal Pendidikan Islam 6, no. 2 (2014): 403.

Sadewo, FX Sri. Meneliti Itu Mudah (Petunjuk Praktis Untuk Melakukan Penelitian Sosial Kualitatif). 1. Edited by MartiNUs Legowo. Surabaya: Unesa University Press, 2016.

Susilo, Aditya, C. Martin Rumende, Ceva W Pitoyo, Widayat Djoko Santoso, Mira Yulianti, Herikurniawan, Robert Sinto, et al. "Coronavirus Disease 2019: Review Of Current Literatures." Jurnal Penyakit Dalam Indonesia 7, no. 1 (2020): 45-67.

Syawaludin, Mohammad. "Alasan Talcott Parsons Tentang Pentingnya Pendidikan Kultur." Jurnal Ijtimaiyya 7, no. 1 (2014): 2-18.

Tobroni, Faiq. "Pembatasan Kegiatan Keagamaan Dalam Penanganan Covid-19." Jurnal Komunikasi Hukum (JKH) 2, no. 2 (2020): 270.

Trilaksana, Hikmah NUr Hidayah dan Agus. "Perkembangan Muslimat NU Cabang Lamongan Bidang Ekonomi Dan Koperasi Kelompok Usaha Bersama (Kube) Tahun 1994-2015." AVATARE, e-Journal Pendidikan Sejarah 5, no. 3 (2017): 584.

Wahid, Muhammad Irfan. "Dari Tradisional MeNUju Digital: Adopsi Internet Oleh Nadhlatul Ulama Selama Pandemi Covid-19." Jurnal Studi Agama dan Masyarakat 16, no. 1 (2020): 73-84.

Yuliana. "Corona Virus Diseases Covid-19: Sebuah Tinjauan Literatur." Journal Wellness And Healtby Magazine 2, no. 1 (2020): 87. 